\title{
KONVERSI LAHAN PERTANIAN DAN KETERKAITANNYA DENGAN KELAS KEMAMPUAN LAHAN SERTA HIRARKI WILAYAH DI KABUPATEN BANDUNG BARAT
}

\section{Agricultural land conversion and its relation with land capability and regional hierarchy in West Bandung Regency}

\author{
Santun Risma Pandapotan Sitorus ${ }^{1{ }^{*}}$, Mila Mulyani2), dan Dyah Retno Panuju ${ }^{1)}$ \\ 1)Departemen Ilmu Tanah dan Sumberdaya Lahan, Fakultas Pertanian IPB, Jl. Meranti Kampus IPB Darmaga \\ Bogor 16680
}

2)Alumni Program Studi Manajemen Sumberdaya Lahan, Fakultas Pertanian IPB, J1. Meranti Kampus IPB Darmaga Bogor 16680

\begin{abstract}
Process of development tends to accelerate population growth and intensify land use conversion. Agricultural land conversion to non-agricultural uses is a common phenomenon to the state. This study aims: (1) to analyze land use change in the period of 1998 to 2008 in Regency of West Bandung (2) to identify rate of change types based on land capability, (3) to figure out hierarchy of sub districts in Regency of West Bandung, and (4) to determine factors influencing land use change. During the period of 1998 to 2008, there were massive conversion of agricultural land at about 2,249ha or 264 ha per annum. Batujajar sub district experienced the biggest change equals to 31.9\% per annum. The most extensive conversion occurred in land capability class I (1,622 ha). Food-crops-cultivated low land (TPLB) was mostly converted into food-crops-cultivated dry land (TPLK). In addition, other types of change were spread on land capability classes II, III, IV, VI, VII, and VIII. Scalogram was utilized to identify West Bandung Regency level of development for the years of 2003 and 2008. Some villages were experiencing significant improvement on the level of development. In 2003 the percentage of the village classified as hierarchies I, II, and III were $15.1 \%, 20.7 \%$ and $64.3 \%$, respectively. Increasing percentage occurred in the hierarchies II and III, while the hierarchy I was decreasing. Factors affecting agricultural land use change were rainfall (in very low, low, and high classes), acreage of built up land in 1998, population density, and development of educational facilities, respectively.
\end{abstract}

Keywords: Agricultural land conversion, built up land, dryland food crops, hierarchy, wetland foodcrops

\begin{abstract}
ABSTRAK
Perkembangan suatu wilayah cenderung akan berpengaruh terhadap peningkatan jumlah penduduk di suatu wilayah, sehingga menimbulkan kekhawatiran akan perubahan luasan suatu jenis penggunaan lahan. Terkonversinya lahan pertanian menjadi lahan non-pertanian merupakan masalah serius pada kondisi tersebut. Penelitian ini bertujuan untuk (1) menganalisis perubahan penggunaan lahan pada periode tahun 1998 dan 2008 di Kabupaten Bandung Barat, (2) menganalisis perubahan penggunaan lahan dalam berbagai kelas kemampuan lahan, (3) menetapkan hirarki kecamatan dan kaitannya dengan perubahan penggunaan lahan, dan (4) menganalisis faktor-faktor yang mempengaruhi perubahan penggunaan lahan. Selama periode tahun 1998 sampai 2008 telah terjadi konversi luas lahan pertanian menjadi lahan terbangun sebesar 2,249 ha dengan laju konversi per tahun 264 ha. Kecamatan Batujajar merupakan kecamatan yang mengalami perubahan penggunaan terluas yaitu sebesar 31.9\%. Sebaran perubahan penggunaan lahan paling luas terdapat pada kelas kemampuan lahan I sebesar 1,622 ha yaitu konversi TPLB menjadi TPLK. Selain itu, perubahan penggunaan lahan jenis lainnya tersebar pada kelas kemampuan lahan II, III, IV, VI, VII, dan VIII. Perkembangan wilayah di Kabupaten Bandung Barat berdasarkan analisis skalogram tahun 2003 dan 2008, menunjukkan adanya peningkatan tingkatan hirarki tiap desa. Pada tahun 2003 persentase desa berhirarki I, II, dan III, berturut-turut sebesar 15.1\%, 20.7\%, dan 64.3\%. Peningkatan hirarki terjadi pada hirarki II dan III, sedangkan hirarki I mengalami penurunan. Faktor-faktor yang berpengaruh sangat nyata terhadap perubahan penggunaan lahan di Kabupaten Bandung Barat adalah curah hujan kelas sangat rendah, rendah, dan tinggi, penggunaan lahan terbangun tahun 1998, kepadatan penduduk, dan pertambahan fasilitas pendidikan.
\end{abstract}

Kata kunci: Konversi lahan pertanian, lahan terbangun, tanaman pangan lahan kering, hirarki, tanaman pangan lahan basah

\section{PENDAHULUAN}

Pertumbuhan ekonomi Indonesia yang terus meningkat secara fluktuatif berdampak pada meningkatnya perkembangan wilayah. Perkembangan suatu wilayah ditandai oleh perkembangan sektor ekonomi dan peningkatan kelengkapan fasilitas-fasilitas umum seperti sekolah, pertokoan, industri, dan lain sebagainya. Sejalan 
dengan itu, pembangunan fasilitas umum yang masif di wilayah yang berkembang menjadi daya tarik penduduk wilayah lain dan proses ini mendorong pertambahan penduduk secara signifikan. Salah satu permasalahan akibat meningkatnya perkembangan suatu wilayah adalah persaingan yang semakin tajam dalam pemanfaatan lahan khususnya antara lahan pertanian dan lahan non-pertanian. Persaingan ini didorong oleh peningkatan kebutuhan sumberdaya lahan untuk berbagai jenis kebutuhan seperti kebutuhan pangan, permukiman dan area beraktifitas berupa pelayanan umum. Kebutuhan pangan membutuhkan lahan pertanian untuk berproduksi, sedangkan permukiman dan sarana pelayanan umum membutuhkan kawasan permukiman dan lahan terbangun. Dalam kondisi demikian, penggunaan lahan pertanian akan berpeluang besar untuk dialihgunakan menjadi penggunaan non-pertanian. Berdasarkan teori nilai ekonomi lahan secara umum dinyatakan bahwa nilai ekonomi lahan pertanian umumnya lebih rendah dibandingkan dengan lahan non-pertanian. Perbedaan nilai tersebut menjadi salah satu sebab terjadinya perubahan penggunaan lahan pertanian menjadi non-pertanian (Nasoetion dan Winoto, 1996).

Menurut Lopulisa (1995) faktor-faktor yang mempengaruhi pola dan jenis penggunaan lahan di Indonesia adalah sifat fisik lahan (iklim, topografi, drainase, sifat fisik dan kimia tanah, dan lain-lain), kondisi faktor budaya dan ekonomi serta kebijakan pemerintah. Besarnya kontribusi faktor-faktor tersebut akan sangat beragam menurut waktu dan ruang. Selain itu, Direktur Jenderal RKLS (2008) menyatakan bahwa faktor-faktor yang dapat mempengaruhi konversi atau perubahan penggunaan suatu lahan diantaranya adalah aspek fisik, ekonomi, sosial dan lain-lain. Beberapa hasil penelitian terdahulu menunjukkan daerah-daerah yang mengalami perkembangan seperti Kabupaten Tangerang mengalami perubahan penggunaan lahan cukup masif (Sitorus et al., 2009). Bandung merupakan ibukota Provinsi Jawa Barat yang perkembangan wilayahnya sangat dinamis. Oleh karena itu, penelitian di Kabupaten Bandung Barat perlu dilakukan mengingat kabupaten ini relatif baru dan hasil pemekaran dari Kabupaten Bandung yang ditetapkan berdasarkan UU No 12 Tahun 2007 tentang pembentukan Kabupaten Bandung Barat di Provinsi Jawa Barat. Selain itu, sebagian wilayah Kabupaten Bandung Barat dilintasi oleh akses jalan tol dan merupakan kawasan andalan cekungan Bandung sehingga perkembangan dan pertumbuhan wilayahnya tidak terlepas dari daya dukung wilayahnya. Daya dukung wilayah merupakan aspek penting yang perlu dipertimbangkan dalam pengembangan suatu wilayah. Beberapa kasus menunjukkan pembangunan yang tidak mempertimbangkan daya dukung wilayah menyebabkan berbagai permasalahan lingkungan seperti banjir dan longsor. Penelitian ini penting dilakukan untuk mengetahui keterkaitan pola perubahan penggunaan lahan dengan kelas kemampuan lahan sebagai indikasi daya dukung wilayah serta kaitannya dengan perkembangan wilayahnya.

Tujuan penelitian ini adalah (1) Menganalisis perubahan penggunaan lahan periode waktu tahun 1998 dan 2008 di Kabupaten Bandung Barat, (2) Mengidentifikasi perubahan penggunaan lahan dalam berbagai kelas kemampuan lahan, (3) Mengetahui hirarki desa, dan (4) Menetapkan faktor-faktor yang mempengaruhi terjadinya perubahan penggunaan lahan.

\section{BAHAN DAN METODE}

Penelitian dilakukan di Kabupaten Bandung Barat, Provinsi Jawa Barat.Kabupaten Bandung Barat terdiri dari 15 kecamatan dan 165 desa. Kecamatan yang mengalami pemekaran yaitu Kecamatan Cililin dan Gununghalu. Kecamatan Cililin dimekarkan menjadi Kecamatan Cililin dan Cihampelas, Kecamatan Gununghalu dimekarkan menjadi Kecamatan Gununghalu dan Rongga. Peta administrasi Kabupaten Bandung Barat pada Gambar 1.

Sebagian dari wilayah Kabupaten Bandung Barat dilintasi Jalan Tol Cipularang yang menghubungkan Kota Jakarta dan Bandung. Tol ini membentang dari CikampekPuwakarta sampai Padalarang. Selain itu, juga terdapat Jalan Tol Padalarang-Cileunyi. Namun dari kedua jalan tol tersebut hanya beberapa kecamatan yang dilintasi jalan tol, seperti Jalan Tol Cipularang melintasi Kecamatan Cikalongwetan, Cipatat, dan Padalarang, sedangkan Jalan Tol Padalarang melintasi Kecamatan Padalarang khususnya Desa Mekarsari.

Data yang digunakan dalam penelitian ini adalah data primer dan data sekunder. Data primer berupa data Citra Landsat 1998 dan 2008 diperoleh dari BIOTROP. Data sekunder berupa Peta Administrasi, Peta Jenis Tanah, Peta Curah Hujan, Peta Lereng, Peta Tekstur, Peta Jalan, dan informasi terkait dengan Kabupaten Bandung Barat. Data Kabupaten Dalam Angka tahun 1998 dan 2008 diperoleh dari Badan Pusat Statistik (BPS). Data Potensi Desa diperoleh dari Studio Bagian Perencanaan dan Pengembangan Wilayah. Alat yang digunakan dalam penelitian adalah komputer dengan software Arcview 3.3, SPSS 16, Microsoft office, dan GPS (Global Positioning System).

\section{Identifikasi Tutupan dan Perubahan Tutupan Lahan serta Analisis Kemampuan Lahan}

\section{Analisis Data Spasial}

Analisis data spasial yang dilakukan adalah menganalisis Citra Landsat dan peta-peta. Tahapan proses analisis terdiri dari koreksi geometri, proses interpretasi visual citra, dan delineasi batas tutupan lahan. Proses ini dilakukan terhadap Citra Landsat 1998 dan 2008. Hasil interpretasi dan tumpang tindih pada kedua titik tahun yang diinterpretasikan adalah peta perubahan penggunaan lahan selama sepuluh tahun, periode 1998-2008. Selanjutnya dilakukan dijitasi dan tumpang tindih Peta Jenis Tanah, Peta Curah hujan, Peta Tekstur, dan Peta Kemiringan untuk menghasilkan Peta Kelas Kemampuan Lahan. Hasil analisis tersebut digunakan sebagai dasar untuk menetapkan titik lokasi pengecekan lapang. Jumlah titik pengecekan lapang 70 titik (Gambar 2). Pengecekan lapang dilakukan untuk mengetahui kondisi penggunaan lahan saat ini untuk memperoleh hasil akhir perubahan penggunaan lahan. 

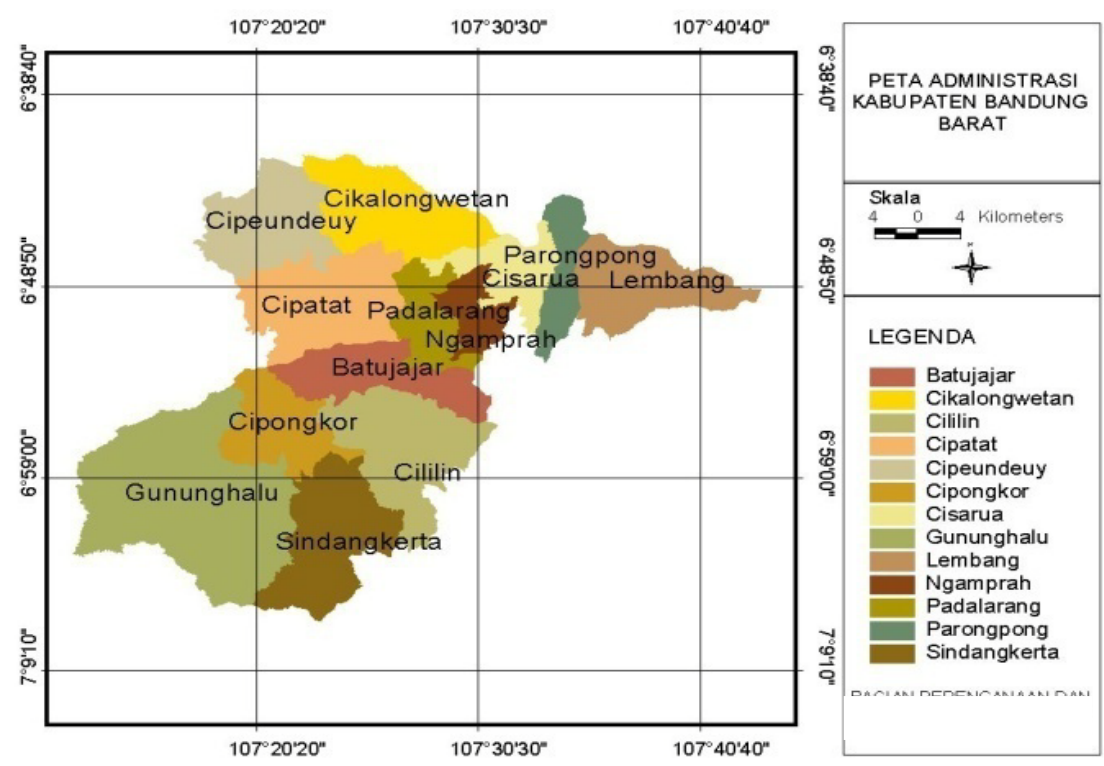

Gambar 1. Peta administrasi Kabupaten Bandung Barat

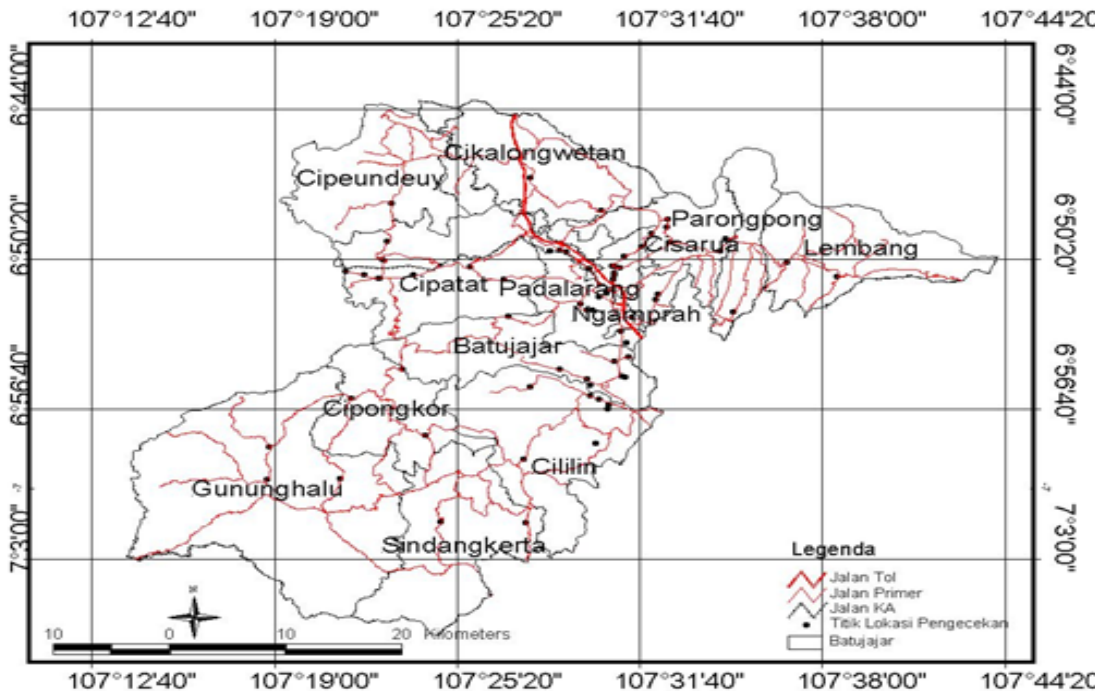

Gambar 2. Peta lokasi pengecekan lapang di Kabupaten Bandung Barat

Selanjutnya untuk mengetahui pertumbuhan penduduk digunakan persamaan pertumbuhan sebagai berikut:

$$
\text { Perubahan }=\frac{\left(x_{t 1}-x_{t o}\right)}{\Delta t}
$$

dimana: $x_{\mathrm{t} 0}=$ jumlah penduduk, luas penggunaan lahan, PDRB atau jumlah fasilitas tahun 1998; $x_{\mathrm{t} 1}=$ jumlah penduduk, luas penggunaan lahan atau jumlah fasilitas tahun $2008 \mathrm{~s}=$ selisih waktu data yang dianalisis.

Model pertumbuhan ini diaplikasikan pada variabel kepadatan penduduk, luas setiap jenis penggunaan lahan, penduduk menurut lapangan usaha dan PDRB menurut lapangan usaha. Dalam penelitian ini perhitungan menggunakan jumlah penduduk dan luas penggunaan lahan yang terdapat dalam suatu wilayah.

\section{Identifikasi Tingkat Perkembangan Wilayah}

Perkembangan wilayah dianalisis dengan menggunakan metode skalogram. Penetapan hirarki di suatu wilayah didasarkan pada jumlah dan jenis fasilitas, serta jarak ke fasilitas tersebut. Dalam penelitian ini dibagi berdasarkan fasilitas ekonomi, sosial dan pendidikan, serta jarak ke berbagai jenis fasilitas tersebut. Variabel data yang digunakan tertera pada Tabel 1. 
Tabel 1. Variabel fasilitas yang digunakan dalam analisis skalogram

\begin{tabular}{|c|c|}
\hline $\begin{array}{l}\text { Kelompok Indeks } \\
\text { Perkembangan }\end{array}$ & Variabel yang Digunakan \\
\hline Fasilitas Pendidikan & $\begin{array}{l}\text { - Jumlah TK negeri dan swasta } \\
\text { - Jumlah SD negeri dan swasta } \\
\text { - Jumlah SLTP negeri dan swasta } \\
\text { - Jumlah SLTA negeri dan swasta } \\
\text { - Jumlah Perguruan Tinggi }\end{array}$ \\
\hline Fasilitas Sosial & $\begin{array}{l}\text { - Jumlah Mesjid } \\
\text { - Jumlah Surau } \\
\text { - Jumlah Gereja } \\
\text { - Jumlah Wihara }\end{array}$ \\
\hline Fasilitas Ekonomi & $\begin{array}{l}\text { - Jumlah Industri besar } \\
\text { - Jumlah Industri kecil } \\
\text { - Jumlah pasar dan pertokoan } \\
\text { - Jumlah Koperasi }\end{array}$ \\
\hline Aksesibilitas Pendidikan & $\begin{array}{l}\text { - Jarak ke TK terdekat } \\
\text { - Jarak ke SD terdekat } \\
\text { - Jarak ke SLTA terdekat }\end{array}$ \\
\hline Aksesibilitas Ekonomi & $\begin{array}{l}\text { - Jarak pertokoan terdekat } \\
\text { - Jarak pasar terdekat }\end{array}$ \\
\hline
\end{tabular}

Adapun kriteria pengelompokkan hirarki adalah sebagai berikut:

- Hirarki I : Jika nilai Indeks Perkembangan Kecamatan (IPK) lebih besar dari nilai simpangan baku (stdev) dan rata-rata (average) (IPK $>$ (Stdev+Average $)$ ).

- Hiraki II : Jika nilai Indeks Perkembangan Kecamatan lebih besar atau sama dengan rata-rata (IPK $\geq$ Average).

- Hirarki II : Jika nilai Indeks Perkembangan Kecamatan lebih kecil dari rata-rata (IPK< $<$ Average).

\section{Analisis Faktor-Faktor yang Mempengaruhi Perubahan Penggunaan Lahan}

Faktor-faktor yang mempengaruhi perubahan penggunaan lahan dianalisis dengan menggunakan Logistic Regression Analysis. Logistic Regression merupakan pendekatan pemodelan statistik untuk mendeskripsikan hubungan dari beberapa variabel penduga (X1,X2,..,Xk) dengan variabel tujuan. Persamaan dari model logistik untuk penetapan faktor penentu perubahan penggunaan lahan tersebut adalah (Hosmer dan Lemeshow, 1989):

$$
\pi(x)=\frac{\exp (g(x))}{1+\exp (g(x))} ; g(x)=\hat{a}_{0}+\hat{a}_{1} x_{1}+\ldots+\hat{a}_{p} x_{p}
$$

Dimana: $\pi(\mathrm{x})=$ Kejadian perubahan penggunaan lahan; $\mathrm{g}(\mathrm{x})=$ Variabel penduga; $\mathrm{a}_{\mathrm{i}}=$ koefisien .

Variabel $\pi(\mathrm{x})$ merupakan kejadian perubahan penggunaan berprinsip binomial yang dalam penelitian ini dibatasi jika satu satuan data mengalami perubahan penggunaan lahan menjadi lahan terbangun diberi kode 1 (satu) dan jika satu satuan data tidak mengalami perubahan penggunaan lahan menjadi lahan terbangun diberi kode 0 (nol). Untuk memperoleh nilai koefisien a digunakan proses tranformasi logistik, sehingga model tersebut disebut sebagai model regresi logistik. Analisis tersebut dapat menunjukkan peluang (kemungkinan) terjadinya perubahan penggunaan lahan (Kleinbaum et al., 2008). Analisis untuk mengetahui faktor penentu perubahan penggunaan lahan menggunakan metode Logistic
Regression dengan prinsip Forward Stepwise. Variabel yang digunakan sebagai variabel penduga adalah jenis tanah, kemiringan lereng, curah hujan, tekstur tanah, penggunaan lahan 1998, jarak dari jalan tol dan jalan kabupaten $\left(\mathrm{km}^{2}\right)$, luas poligon tiap penggunaan lahan $\left(\mathrm{km}^{2}\right)$, pertambahan fasilitas pendidikan, ekonomi, dan sosial, serta pertambahan jumlah penduduk, jumlah penduduk, dan kepadatan penduduk. Variabel tujuan yaitu perubahan penggunaan lahan menjadi lahan terbangun, sedangkan variabel penduga terdiri dari 13 variabel. Variabel-variabel yang digunakan disajikan pada Tabel 2.

Tabel 2. Variabel-variabel dalam Logistic Regression Analysis

\begin{tabular}{lll}
\hline \multicolumn{1}{c}{ Variabel Tujuan (Y) } & \multicolumn{2}{c}{ Variabel Penduga (X) } \\
\hline Variabel perubahan & 1. & Jenis tanah \\
penggunaan lahan $(0=$ & 2. & Kemiringan lereng \\
tidak berubah; 1 = berubah) & 3. & Curah hujan \\
& 4. & Tekstur \\
& 5. & Luas tiap pengunaan lahan \\
& 6. & Pertambahan jumlah penduduk \\
& 7. & Pertambahan fasilitas pendidikan \\
& 8. & Pertambahan fasilitas ekonomi \\
& 9. & Pertambahan fasilitas social \\
& 10. Jarak ke jalan tol \\
& 11. Jarak ke kabupaten \\
& 12. Jumlah penduduk \\
& 13. & Kepadatan penduduk \\
\hline
\end{tabular}

Analisis data penduduk dan data sosial ekonomi berbasis wilayah administratif, sedangkan data penggunaan lahan dan sebaran karakteristik untuk membangun kemampuan lahan berbasis poligon. Untuk melakukan matching data basis administratif dan data basis poligon tersebut digunakan asumsi bahwa penduduk dan segala aktifitas sosial ekonomi tersebar proporsional sesuai luasan setiap poligon penggunaan lahan terbangun.

\section{HASIL DAN PEMBAHASAN}

\section{Perubahan Penggunaaan Lahan Tahun 1998 dan 2008 di Kabupaten Bandung Barat}

Kabupaten Bandung Barat memiliki sebaran penggunaan lahan yang beragam. Namun dalam penelitian ini hanya dianalisis lima jenis penggunaan lahan yaitu badan air, hutan, lahan terbangun, tanaman pertanian lahan basah (TPLB), dan tanaman pertanian lahan kering (TPLK). Hal ini karena data yang digunakan untuk mengidentifikasi jenis penggunaan lahan adalah citra Landsat dengan resolusi spasial 30 meter dan kelima jenis penggunaan lahan tersebut relatif mudah diidentifikasi kenampakannya. Perubahan luas penggunaan lahan tahun 1998 dan 2008 tertera pada Tabel 3.

Tabel 3. Luas penggunaan lahan di Kabupaten Bandung Barat pada tahun 1998 dan 2008

\begin{tabular}{|c|c|c|c|}
\hline \multirow{2}{*}{ Penggunaan lahan } & \multicolumn{2}{|c|}{ Luas (ha) } & \multirow{2}{*}{$\begin{array}{c}\text { Perubahan } \\
\text { (ha tahun }^{-1} \text { ) }\end{array}$} \\
\hline & 1998 & 2008 & \\
\hline Badan air & 1,081 & 1,084 & 0.30 \\
\hline Hutan & 14,116 & 13,722 & -39.4 \\
\hline Lahan terbangun & 27,494 & 30,134 & 264 \\
\hline TPLB & 32,691 & 29,603 & -309 \\
\hline TPLK & 48,264 & 49,103 & 83.9 \\
\hline $\begin{array}{l}\text { Lahan Pertanian (TPLB } \\
\text { \& TPLK) }\end{array}$ & 80,955 & 78,706 & -225 \\
\hline
\end{tabular}


Pada tahun 1998 jenis penggunaan lahan yang paling luas adalah tanaman pertanian lahan kering yaitu 48,264 ha, sedangkan untuk jenis penggunaan lahan terkecil sebesar 1,081 ha adalah badan air. Demikian juga pada tahun 2008 jenis penggunaan lahan terluas adalah tanaman pertanian lahan kering sebesar 49,103 ha, dan jenis penggunaan lahan terkecil luasnya adalah badan air sebesar 1,084 ha.

Laju penurunan penggunaan lahan pertanian yaitu TPLB dan TPLK di Kabupaten Bandung Barat sebesar 225 ha per tahun. Laju peningkatan luas jenis penggunaan lahan pada tahun 1998 dan 2008 paling besar terjadi pada jenis penggunaan lahan terbangun sebesar 264 ha per tahun. Hal ini mengindikasikan bahwa adanya penambahan pembangunan, baik berupa fasilitas-fasilitas umum maupun pemukiman penduduk.

\section{Pola Perubahan Penggunaan Lahan}

Perubahan penggunaan lahan yang terjadi di Kabupaten Bandung Barat pada tahun 1998 dan 2008 tertera pada Tabel 4. Di Kabupaten Bandung Barat telah terjadi perubahan penggunaan lahan TPLB dan TPLK menjadi lahan terbangun.

Selama kurun waktu sepuluh tahun yaitu tahun 1998 sampai 2008, TPLB terkonversi menjadi lahan terbangun sebesar 1,241 ha dan menjadi TPLK sebesar 2,114 ha. Lahan TPLK yang mengalami penurunan luas karena terkonversi menjadi lahan terbangun sebesar 1,398 ha. Hal ini diduga karena pertambahan jumlah penduduk yang membutuhkan lahan untuk perumahan dan berbagai fasilitas umum dan fasilitas sosial. Terkait dengan perubahan penggunaan lahan pertanian, hal yang sama juga ditunjukkan hasil penelitian Sitorus et al. (2009) di Kabupaten Tangerang yang menunjukkan laju konversi lahan pertanian (TPLK dan TPLB) sebesar 2,409 ha atau $2.4 \%$ per tahun. Selain terkonversi menjadi penggunaan lahan yang lain, TPLK juga mengalami penambahan luas yang berasal dari penggunaan lain yaitu dari TPLB sebesar 2,114 ha. Hal ini antara lain disebabkan sebagian areal TPLB tidak mendapatkan air dari saluran irigasi karena adanya pembangunan dan sebagian lagi atas kehendak pemilik lahan yang menutup saluran air ke areal TPLB. Laju perubahan penggunaan lahan pada periode tahun 1998 dan 2008 secara grafik disajikan pada Gambar 3.

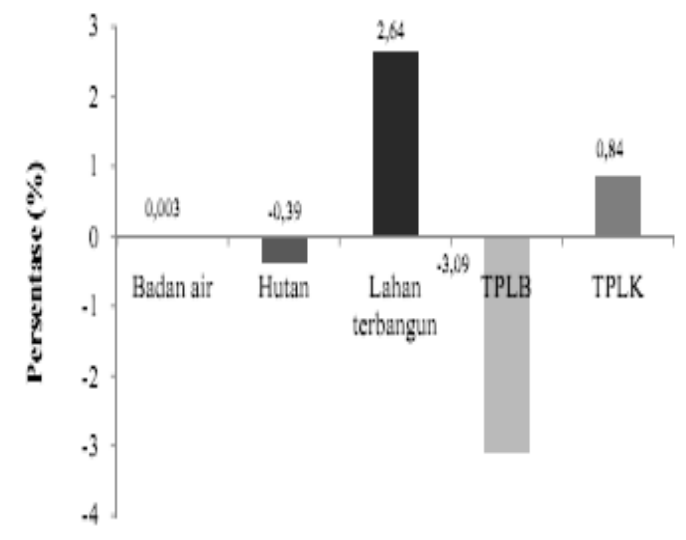

Pengunaan Lahan

Gambar 3. Perubahan penggunaan lahan tahun 1998 dan 2008

Perubahan penggunaan lahan per kecamatan disajikan pada grafik perubahan penggunaan lahan per kecamatan (Gambar 4) dan secara spasial sebaran perubahan penggunaan lahan ditampilkan pada Gambar 6. Persentase perubahan penggunaan lahan per kecamatan di Kabupaten Bandung Barat beragam. Kecamatan Batujajar mengalami luas perubahan terbesar sebesar $31.9 \%$ dari luas perubahan, sedangkan yang terkecil di Kecamatan Cipongkor sebesar $0.25 \%$. Hal ini diduga karena Kecamatan Batujajar merupakan kecamatan yang mengalami perkembangan wilayah yang relatif cepat sehingga terjadi perubahan penggunaan lahan dari lahan bervegetasi/tanaman menjadi kawasan terbangun.

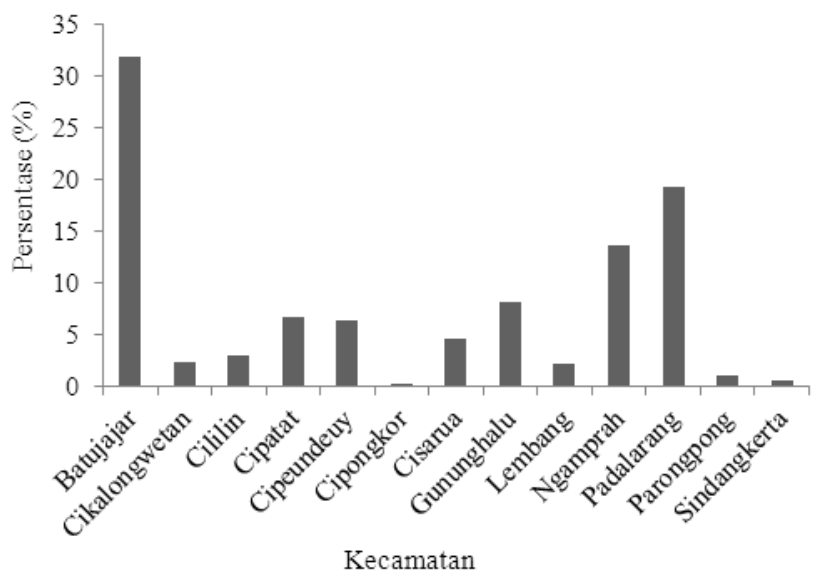

Gambar 4. Perubahan penggunaan lahan per kecamatan di Kabupaten Bandung Barat pada periode tahun 1998 dan 2008

Tabel 4. Pola perubahan penggunaan lahan dan luasnya pada periode tahun 1998 dan 2008

\begin{tabular}{|c|c|c|c|c|c|c|}
\hline \multirow{2}{*}{$\begin{array}{l}\text { Penggunaan Lahan } \\
1998 \text { (ha) }\end{array}$} & \multicolumn{5}{|c|}{ Penggunaan Lahan 2008 (ha) } & \multirow{2}{*}{$\begin{array}{l}\text { Jumlah (ha) } \\
\text { Tahun } 1998 \\
\end{array}$} \\
\hline & $\begin{array}{l}\text { Badan } \\
\text { air }\end{array}$ & Hutan & $\begin{array}{l}\text { Lahan } \\
\text { terbangun }\end{array}$ & TPLB & TPLK & \\
\hline Badan air & 1,081 & & & & & 1,081 \\
\hline Hutan & & 13,722 & & 145 & 248 & 14,116 \\
\hline Lahan Terbangun & & & 27,494 & & & 27,494 \\
\hline TPLB & & & 1,241 & 29,335 & 2,114 & 32,691 \\
\hline TPLK & 3.01 & & 1,398 & 122 & 46,740 & 48,264 \\
\hline $\begin{array}{l}\text { Jumlah (ha) Tahun } \\
2008\end{array}$ & 1,084 & 13,722 & 30,134 & 29,603 & 49,103 & 123,647 \\
\hline
\end{tabular}



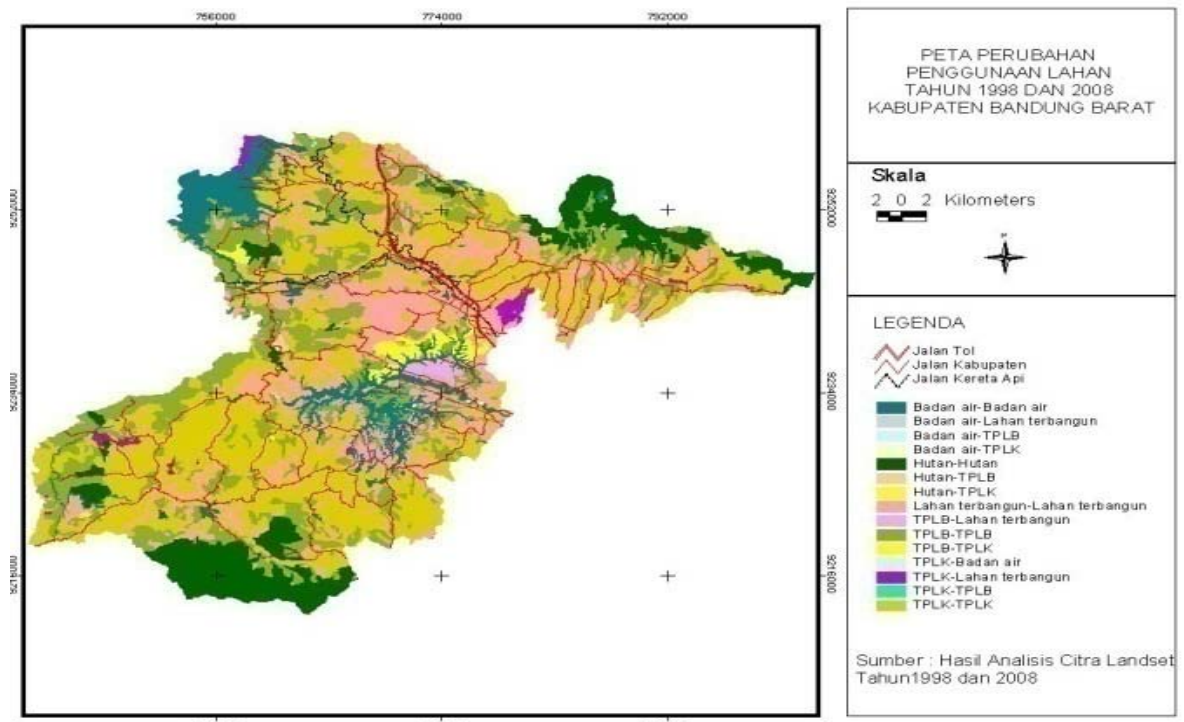

Gambar 6. Peta perubahan penggunaan lahan tahun 1998 dan 2008

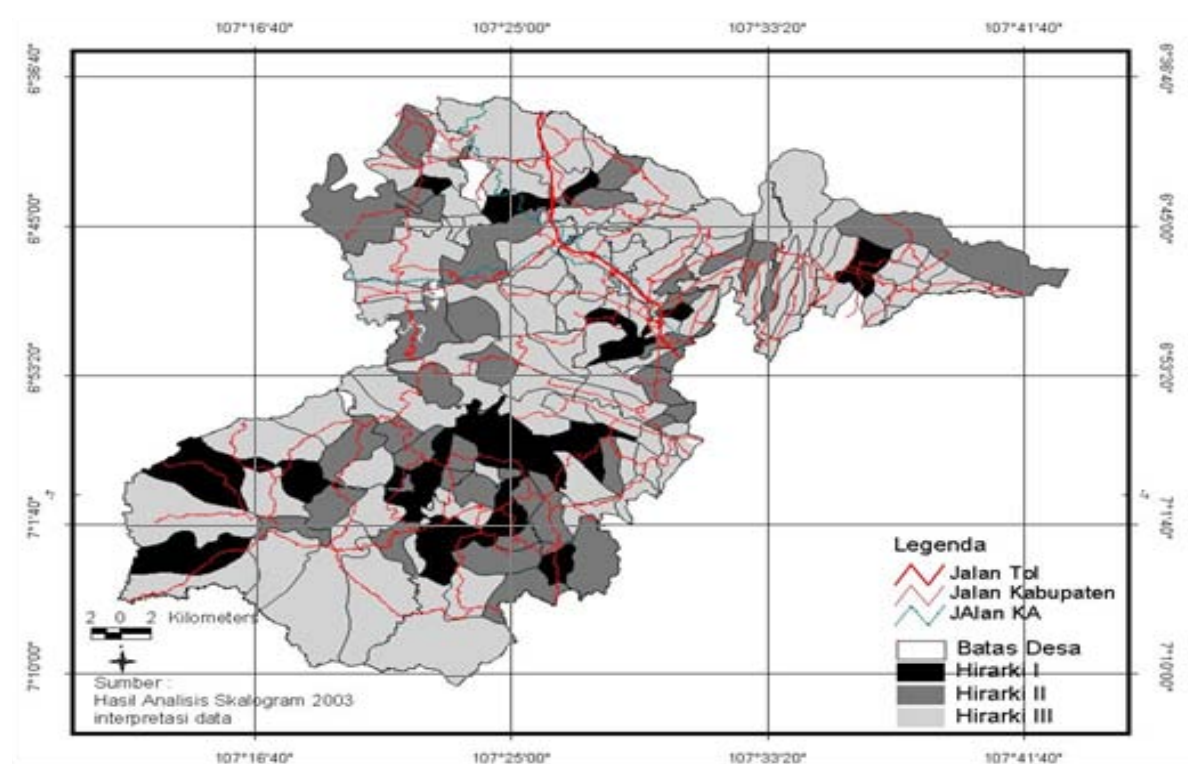

Gambar 7. Peta hirarki Kabupaten Bandung Barat tahun 2003

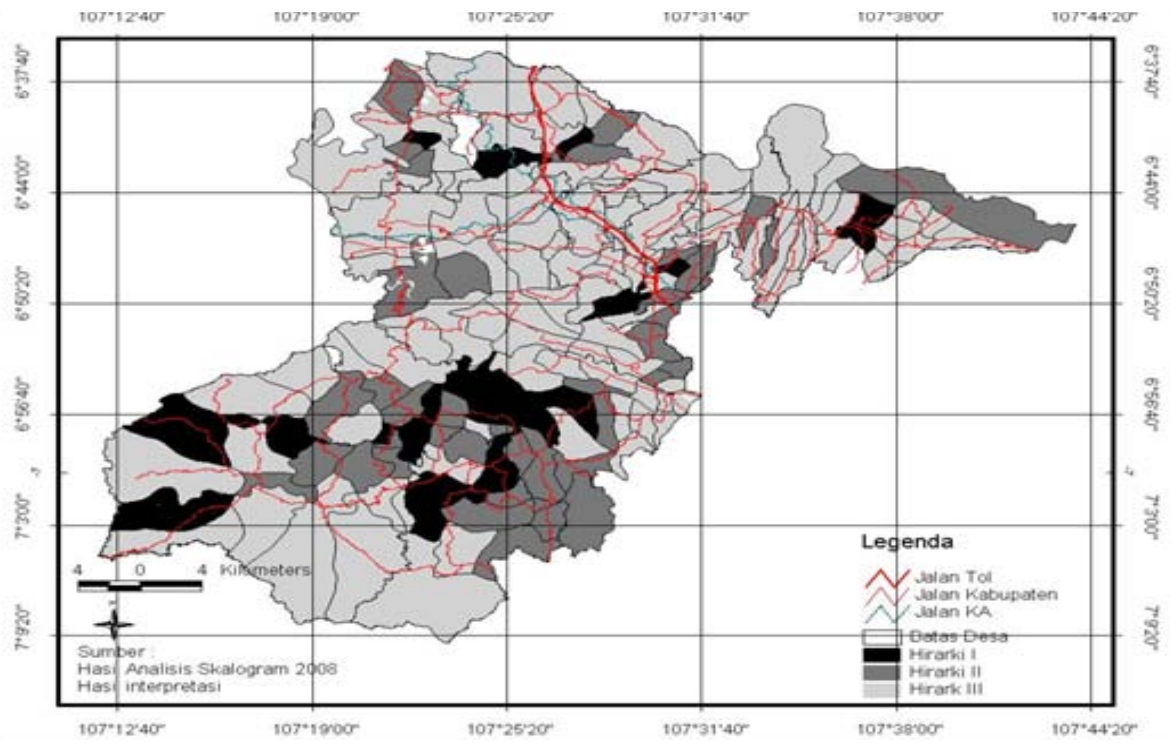

Gambar 8. Peta hirarki Kabupaten Bandung Barat tahun 2008 


\section{Keterkaitan Perubahan Penggunaan Lahan dengan Kelas Kemampuan Lahan}

Perubahan penggunaan lahan pada berbagai kelas kemampuan lahan yang secara spasial disajikan pada Gambar 5. Perubahan penggunaan lahan terluas terjadi pada lahan berkelas kemampuan lahan I. Pada kelas kemampuan lahan ini jenis penggunaan TPLB yang terkonversi menjadi TPLK sebesar 1,622 ha, dan TPLB yang terkonversi menjadi lahan terbangun sebesar 962 ha. Hal ini diduga terjadi pada lahan berkelas kemampuan 1 yang berlokasi di sekitar perkotaan. Sehingga areal tersebut menjadi sangat strategis untuk dijadikan perumahan, kegiatan ekonomi dan perdagangan serta lokasi berbagai fasilitas umum dan fasilitas sosial.

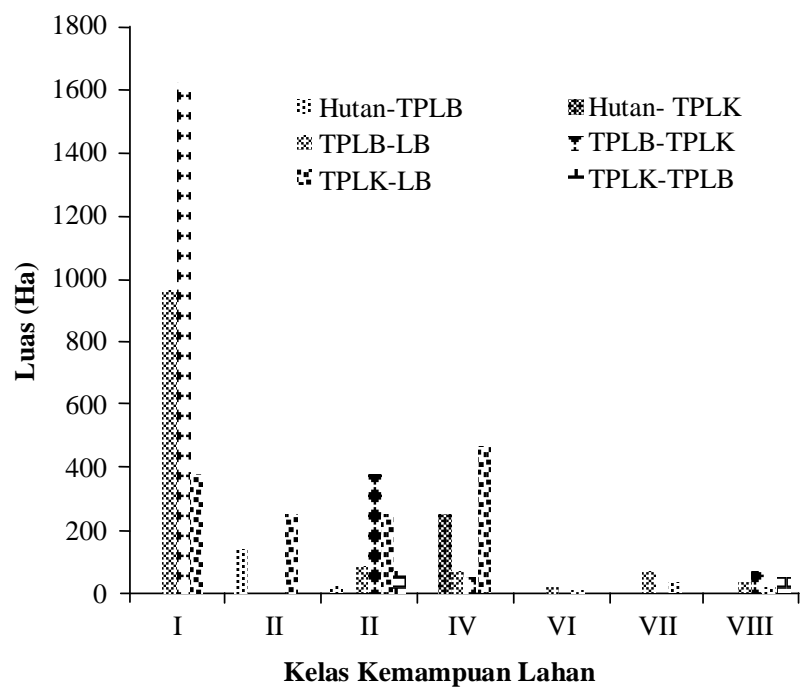

Gambar 5. Luas perubahan penggunaan lahan pada berbagai kelas kemampuan lahan

\section{Perkembangan Wilayah Kabupaten Bandung Barat}

Kebutuhan lahan untuk berbagai aktivitas manusia akan meningkat sejalan dengan perkembangan wilayah. Demikian juga peningkatan jumlah penduduk, akan mendorong pertambahan jumlah dan jenis fasilitas yang ada. Hal ini dapat dilihat dari hasil analisis jumlah dan jenis fasilitas yang ada di 13 kecamatan pada tahun 2003 dan dimekarkan menjadi 15 kecamatan pada tahun 2008 dengan jumlah desa sebanyak 165.

Penentuan hirarki di suatu wilayah dipengaruhi oleh besarnya indeks perkembangan suatu wilayah. Jika wilayah memiliki nilai indeks perkembangan wilayah yang semakin besar maka wilayah tersebut semakin berkembang. Sebaliknya, wilayah yang memiliki nilai indeks perkembangan wilayah yang lebih kecil maka tingkat perkembangan wilayah tersebut tergolong rendah. Perkembangan wilayah yang terjadi di Kabupaten Bandung Barat dianalisis berdasarkan data PODES tahun 2003 dan 2008. Hasil analisis skalogram desa-desa di Kabupaten Bandung Barat dapat dilihat pada Tabel 5.
Tabel 5. Hasil analisis skalogram desa-desa di Kabupaten Bandung Barat Tahun 2003 dan 2008

\begin{tabular}{lcccccc}
\hline \multirow{2}{*}{$\begin{array}{l}\text { Nama } \\
\text { Kecamatan }\end{array}$} & I & II & III & I & II & III \\
\cline { 2 - 7 } & 0 & 23.1 & 76.9 & 0 & 23.1 & 76.9 \\
Batujajar & 30.8 & 23.1 & 46.2 & 15.4 & 15.4 & 69.2 \\
Cikalongwetan & 17.6 & 29.4 & 52.9 & 19.0 & 28.6 & 52.4 \\
Cililin & 8.33 & 0 & 91.7 & 0 & 16.7 & 83.3 \\
Cipatat & 8.33 & 16.7 & 75 & 8.33 & 25 & 66.7 \\
Cipeundeuy & 50 & 42.9 & 7.14 & 21.4 & 50 & 28.6 \\
Cipongkor & 0 & 12.5 & 87.5 & 0 & 12.5 & 87.5 \\
Cisarua & 23.5 & 35.3 & 41.2 & 23.5 & 23.5 & 52.9 \\
Gununghalu & 6.25 & 12.5 & 81.2 & 6.67 & 6.67 & 86.7 \\
Lembang & 18.2 & 9.09 & 72.7 & 0 & 38.5 & 46.1 \\
Ngamprah & 0 & 10 & 90 & 20 & 0 & 80 \\
Padalarang & 0 & 28.6 & 71.4 & 0 & 14.3 & 85.7 \\
Parongpong & 27.3 & 54.5 & 18.2 & 27.3 & 45.4 & 27.3 \\
Sindangkerta & & & & & & \\
Kabupaten & $\mathbf{1 5 . 1}$ & $\mathbf{2 0 . 7}$ & $\mathbf{6 4 . 3}$ & $\mathbf{1 1 . 0}$ & $\mathbf{2 3 . 3}$ & $\mathbf{6 5 . 6}$ \\
Bandung Barat & & & & & & \\
\hline
\end{tabular}

Desa-desa yang terdapat di Kabupaten Bandung Barat mengalami penurunan dan penambahan tingkatan hirarki. Pada tahun 2003 jumlah desa yang paling banyak adalah desa yang memiliki tingkatan hirarki III sebesar 64.3\%, sedangkan hirarki I dan II lebih sedikit yaitu hirarki I (15.1\%) dan hirarki II (20.7\%). Selama kurun waktu 5 tahun (tahun 2008) terjadi perubahan tingkatan hirarki. Jumlah desa paling banyak tiap desa yang berhirarki III dan sedikit meningkat menjadi sebesar 65.6\%. Demikian juga dengan desa-desa yang berhirarki II meningkat jumlahnya menjadi 23.3\%. Sebaliknya, jumlah desa berhirarki I mengalami penurunan menjadi 11.0\%.

Hasil analisis dengan menggunakan metode skalogram di Kabupaten Bandung Barat tahun 2003 dan 2008 berturut-turut dapat dilihat secara spasial pada Gambar 7 dan 8. Pada tahun 2008 desa-desa yang ada di Kecamatan Cikalongwetan mengalami penurunan tingkatan hirarki. Hal ini berkaitan dengan peningkatan indeks perkembangan wilayah yang ada di kecamatankecamatan lainnya salah satunya Kecamatan Padalarang yang pada tahun tersebut (2008) mengalami peningkatan jumlah desa yang berhirarki I sebesar 20\%. Penurunan hirarki I juga terjadi pada Kecamatan Ngamprah yang merupakan Ibukota Kabupaten Bandung Barat. Hal tersebut terjadi karena penetapan Ngamprah pada tahun 2007 sebagai ibukota dari Kabupaten Bandung Barat hanya berselang satu tahun dari analisis hirarki dilakukan (2008), sehingga waktu yang singkat (1 tahun) belum cukup dalam mempengaruhi perkembangan wilayah berkenaan dengan penetapannya sebagai ibukota kabupaten.

\section{Faktor-Faktor yang Mempengaruhi Perubahan Penggunaan Lahan menjadi Lahan Terbangun}

Hasil analisis Logistic Regression terhadap perubahan penggunaan lahan pertanian menjadi lahan terbangun tertera pada Tabel 6. Dari Tabel 6 tersebut diketahui bahwa variabel penduga yang berpengaruh sangat nyata terhadap perubahan penggunaan lahan adalah curah hujan pada kelas rendah, sangat rendah, dan tinggi serta penggunaan lahan tahun 1998 (lahan terbangun), kepadatan penduduk dan pertambahan fasilitas pendidikan. Curah hujan pada kelas sangat rendah, rendah, dan sedang memiliki hubungan yang positif yang bermakna 
berkontribusi dalam peningkatan peluang terjadinya perubahan penggunaan lahan. Sebaran curah hujan di lokasi penelitian cukup bervariasi dari sangat rendah sampai dengan sangat tinggi. Lokasi yang cenderung mengalami perubahan penggunaan lahan adalah lokasi yang memiliki curah hujan sangat rendah sampai dengan sedang. Sebaliknya, lokasi yang memiliki curah hujan sangat tinggi cenderung berpeluang mengalami intensitas perubahan yang rendah. Hujan merupakan kejadian alam yang penting bagi kawasan pertanian dan yang bercurah hujan tinggi umumnya berada di lokasi dengan tingkat ketinggian (altitude) tertentu. Lokasi tersebut umumnya digunakan sebagai kawasan pertanian yang subur. Oleh karena itu, kejadian perubahan di kawasan tersebut relatif rendah. Sebaliknya, wilayah dengan curah hujan rendah berlokasi di dataran lebih rendah dan merupakan kawasan yang menjadi pusat pelayanan umum.

Dua jenis penggunaan lahan tahun 1998 yaitu hutan dan TPLB memiliki hubungan positif dengan peningkatan lahan terbangun di tahun 2008. Hal ini berarti semakin tinggi luas hutan maupun TPLB di suatu wilayah maka peluang terjadinya perubahan penggunaan lahan menjadi lahan terbangun semakin tinggi. Lahan TPLB adalah lahan pertanian yang relatif tersedia dan rentan konversi. Berdasarkan penelitian Winoto et al. (1996) lahan TPLB di sekitar Pantura sebagian dikonversikan setelah sebelumnya mengalami proses pemutusan jaringan irigasi. Proses tersebut dilakukan untuk menghindari aturan yang melarang konversi langsung dari lahan sawah menjadi lahan terbangun.

Tabel 6. Hasil analisis statistik metode Logistic Regression terhadap perubahan penggunaan lahan pertanian menjadi lahan terbangun

\begin{tabular}{|c|c|c|c|c|c|}
\hline Variabel & B & $\begin{array}{l}\text { Galat } \\
\text { baku }\end{array}$ & $\begin{array}{c}\text { Statistik } \\
\text { Wald }\end{array}$ & db & Nilai $\mathbf{P}$ \\
\hline Curah hujan & & & 488 & 5 & $0.00^{*}$ \\
\hline $\begin{array}{l}\text { (Sangat } \\
\text { rendah) }\end{array}$ & 4.52 & 0.26 & 298,701 & 1 & $0.00^{*}$ \\
\hline (Rendah) & 2.63 & 0.24 & 112 & 1 & $0.00 *$ \\
\hline (Sedang) & 1.28 & 40,197 & 0.00 & 1 & 1.00 \\
\hline (Tinggi) & -1.14 & 0.47 & 5.69 & 1 & $0.02^{*}$ \\
\hline (Sangat tinggi) & -2.16 & 1.42 & 2.30 & 1 & 0.13 \\
\hline \multicolumn{6}{|l|}{ Penggunaan } \\
\hline $\begin{array}{l}\text { lahan tahun } \\
1998\end{array}$ & & & 62.5 & 1 & $0.00^{*}$ \\
\hline (Hutan) & 1.47 & 1669 & 0.00 & 3 & 0.99 \\
\hline $\begin{array}{l}\text { (Lahan } \\
\text { terbangun) }\end{array}$ & $-2,966,290$ & 375,324 & 62.5 & 1 & $0.00^{*}$ \\
\hline (TPLB) & 18.1 & 559 & 0.00 & 1 & 0.97 \\
\hline $\begin{array}{l}\text { Kepadatan } \\
\text { penduduk }\end{array}$ & 0.35 & 0.04 & 62.5 & 1 & $0.00^{*}$ \\
\hline $\begin{array}{l}\text { Pertambahan } \\
\text { fasilitas } \\
\text { pendidikan }\end{array}$ & 6.09 & 2.90 & 4.41 & 1 & $0.04^{*}$ \\
\hline Konstanta & -22.5 & 559 & 0.00 & 1 & 0.97 \\
\hline $\begin{array}{r}\text { Keterangan: }{ }^{*} \\
\text { B } \\
\text { ke }\end{array}$ & $\begin{array}{l}\text { igat nyata } \\
\text { konstanta } \\
\text { ahan }\end{array}$ & $\begin{array}{l}\text { ara sta } \\
=\text { der }\end{array}$ & $\begin{array}{l}\text { (p-le } \\
\text { ebas; }\end{array}$ & 0.0 & tingka \\
\hline
\end{tabular}

Variabel pertambahan fasilitas pendidikan dan kepadatan penduduk memiliki hubungan positif dengan perubahan penggunan lahan. Hal ini dapat diartikan bahwa perubahan penggunaan lahan menjadi lahan terbangun di tahun 2008 terutama karena pembangunan fasilitas pendidikan dan pertumbuhan penduduk. Kebutuhan fasilitas pendidikan di wilayah Bandung Barat sebagai wilayah yang baru dimekarkan menjadi salah satu penyebab penting terjadinya perubahan penggunaan lahan menjadi lahan terbangun. Sementara itu, pertumbuhan penduduk yang menuntut tersedianya lokasi permukiman yang memadai juga merupakan sebab penting lain yangmendorong terjadinya konversi lahan pertanian di Kabupaten Bandung Barat.

\section{SIMPULAN}

Kesimpulan dari penelitian di Kabupaten Bandung Barat ini adalah

1. Pada periode tahun 1998 dan 2008, (selang waktu sepuluh tahun) telah terjadi perubahan penggunaan lahan yaitu bertambahnya luasan lahan terbangun, tanaman pertanian lahan kering dan badan air, sedangkan untuk hutan dan tanaman pertanian lahan basah mengalami pengurangan luasan. Kecamatan yang memiliki perubahan penggunaan lahan yang paling besar adalah Kecamatan Batujajar.

2. Perubahan penggunaan lahan terjadi pada kelas kemampuan lahan I, II, III, IV, VI, VII, dan VIII. Perubahan penggunaan lahan yang paling luas terjadi pada lahan kelas I yaitu dari penggunaan lahan TPLB menjadi TPLK dan lahan terbangun.

3. Tingkat perkembangan wilayah yang terjadi di Kabupaten Bandung Barat belum merata, namun perubahan tingkatan hirarki di setiap desa-desa kecamatan sudah menunjukkan adanya perubahan dalam hal penambahan jenis dan jumlah fasilitas. Pada periode 2003 sampai 2008 terjadi peningkatan jumlah desa berhirarki II dan III, sedangkan jumlah yang berhirarki I mengalami penurunan.

4. Faktor-faktor yang berpengaruh nyata terhadap perubahan penggunaan lahan pertanian menjadi lahan terbangun adalah curah hujan kelas sangat rendah, rendah, dan tinggi, penggunaan lahan tahun 1998 (lahan terbangun), kepadatan penduduk dan pertambahan fasilitas pendidikan. Faktor-faktor lainnya yang cenderung berpengaruh terhadap perubahan penggunaan lahan adalah jenis tanah, kemiringan lereng dan jumlah penduduk.

\section{SARAN}

1. Penelitian mengenai perubahan penggunaan lahan disarankan agar dilanjutkan dengan mengambil lebih dari dua titik waktu untuk mengetahui pola perubahan penggunaan lahan yang terjadi.

2. Kabupaten Bandung Barat merupakan wilayah yang baru berkembang sehingga disarankan perlu adanya penelitian untuk mengendalikan terjadinya perubahan penggunaan lahan yang tidak terarah. Selain itu, juga disarankan adanya = penelitian berkaitan dengan perubahan penggunaan lahan yang dikaitkan dengan RTRW Kabupaten Bandung Barat.

\section{DAFTAR PUSTAKA}

Direktur Jendral RKLS. 2008. Penanganan krisis sumberdaya lahan dan pemanfaatan kawasan hutan untuk pengadaan pangan. Prosiding 
Semiloka Nasional Strategi Penanganan Krisis Sumberdaya Lahan untuk Mendukung Kedaulatan Pangan dan Energi. Departemen Ilmu Tanah dan Sumberdaya Lahan. Fakultas Pertanian. Institut Pertanian Bogor, Bogor. hlm 27-36.

Hosmer, D.W. and S, Lemeshow. 1989. Applied Logistic Regression. Wiley-Interscience. New York.

Kleinbaum, D., L. Kupper, and A. Nizam. 2008. Applied Regression Analysis and Other Multivariate Methods. $4^{\text {th }}$ ed. Thomson Higher Education, Belmont, USA.

Lopulisa, C. 1995. Penggunaan lahan dalam perspektif pembangunan keberlanjutan di Indonesia. Prosiding Kongres Nasional VI HITI Penatagunaan Tanah sebagai Perangkat Penataan Ruang Dalam Rangka Meningkatnya Kesejahteraan Rakyat. Himpunan Ilmu Tanah Indonesia. hlm. 168-173.
Nasoetion, L. dan J. Winoto. 1996. Masalah alih fungsi lahan pertanian dan dampaknya terhadap keberlangsungan swasembadapangan. Prosiding Lokakarya Persaingan Dalam Pemanfaatan Sumberdaya Lahan dan Air: Dampaknya terhadap Keberlanjutan Swasembada Beras. Hasil Kerjasama Pusat Penelitian Sosial Ekonomi Pertanian dengan Ford Foundation. Bogor. hlm. 64-82.

Sitorus, S.R.P., R. Putri, dan D.R. Panuju. 2009. Analisis konversi lahan pertanian di Kabupaten Tangerang. J. Tanah Lingk., 11: 41-48.

Winoto, J., N.A. Achsani, B. Barus, D.R. Panuju, F. Tonny, dan M.N. Aidi. 1996. Konversi Lahan dan Dampaknya Terhadap Keberlangsungan Sistem Pertanian di Pantai Utara Jawa Barat. Laporan Penelitian Kerjasama LP-IPB dan ARMP, Badan Penelitian dan Pengembangan Pertanian, Departemen Pertanian. 